\title{
Variations in Serum Gonadotropin and Prolactin Levels during Consecutive Reproductive States in Mongolian Gerbils (Meriones unguiculatus)
}

\author{
Xiao-Hui LV and Da-Zhao SHI \\ College of Agriculture and Biotechnology, China Agricultural University, Beijing 100193, China
}

\begin{abstract}
Serum follicle-stimulating hormone (FSH), luteinizing hormone (LH), and prolactin $(P R L)$ levels were examined during consecutive reproductive states in Mongolian gerbils. The results indicate that FSH, $\mathrm{LH}$, and PRL levels peak at proestrus, estrus, and diestrus, respectively. During early gestation in primiparous gerbils, gonadotropin levels were the lowest on day 6. This was followed by an increase in FSH and LH levels until days 18 and 15 , respectively, with levels remaining constant until day 21 . However, in multiparous gerbils, gonadotropin levels were the lowest on day 12 of gestation and were relatively stable between days 15 to 21 . In both primiparous and multiparous gerbils, gonadotropin levels increased rapidly from day 21 of gestation to day 3 of lactation, and kept stable between 6-24 days of lactation. PRL peaked during early gestation on days 9 and 6 in the primiparous and multiparous gerbils, respectively, followed by a decline. PRL levels subsequently peaked again on day 21 before parturition. During lactation, PRL levels peaked on days 6 and 9 in primiparous and multiparous gerbils, respectively, followed by a decline until lactation ended. These findings suggest that variations in gonadotropin during the estrous cycle, gestation, and lactation in Mongolian gerbils are similar to those observed in rats, whereas prolactin levels differ. Changes in gonadotropin and prolactin levels during different reproductive states were found to be similar in primiparous and multiparous gerbils, and were correlated with the reproductive stages of Mongolian gerbils.
\end{abstract}

Key words: estrous cycle, gestation, gonadotropin, lactation, prolactin

\section{Introduction}

The Mongolian gerbil (Meriones unguiculatus Milne Edwards, 1867) belongs to the subfamily Gerbillinae, and is mainly distributed across the arid steppes, semideserts, and adjacent farming-pastoral areas of North China, Mongolia, and the Baikal Lake region of Russia $[13,24]$. An overabundant population of gerbils can cause serious damage to crops in farming areas. They are also the main reservoir host of Yersinia pestis, which causes plague [13]. The Mongolian gerbil has been extensively used as an experimental animal model in neuroscience, physiology, reproduction, and behavioral research [24]. The estrous cycle of the Mongolian gerbil is 4-7 days; gestation, 24-26 days; lactation, 21-22 days; and the litter size at birth ranges from $1-9[9,10$,

(Received 10 September 2010 / Accepted 12 December 2010)

Address corresponding: D.-Z. Shi, College of Agriculture and Biotechnology, China Agricultural University, No. 2 Yuanmingyuan West Road, Haidian District, Beijing 100193, China 
$18,25]$. We have previously reported the changes in the levels of estradiol and progesterone during the different reproductive states in Mongolian gerbils [15]. However, data on the secretion patterns of reproductive hormones in Mongolian gerbils during different reproductive states remain insufficient $[4,9,10,25,27]$. To our knowledge, this is the first study of the secretion patterns of gonadotropin and prolactin during consecutive reproductive states in Mongolian gerbils, and it therefore contributes to a detailed understanding of their reproductive physiology. The objectives of this study were as follows: first, to validate the variations in serum gonadotropin and prolactin levels during the different reproductive states of Mongolian gerbils and to analyze the differences in secretion patterns between Mongolian gerbils and other rodents such as rats and mice; second, to analyze the differences in variations in gonadotropin and prolactin levels in primiparous and multiparous gerbils; and third, to analyze the relationship between the levels of these 3 hormones and the reproductive stages of Mongolian gerbils.

\section{Materials and Methods}

\section{Animals and sampling}

The Mongolian gerbils used in this study were from an indoor colony bred from animals captured in the $\mathrm{Xi}$ linguole League of Inner Mongolia. The gerbils were maintained at $23 \pm 1{ }^{\circ} \mathrm{C}$ with automatically controlled lighting between 0700 and $2100 \mathrm{~h}$ ( $14 \mathrm{~h}$ light: $10 \mathrm{~h}$ dark). They were provided with a food mixture containing equal parts of corn and sunflower seeds, and were given water ad libitum. Twenty-four, 4-month-old, virgin, female gerbils (55-65 g) with regular estrous cycles of 4 days as confirmed by vaginal smear were used [25]. These gerbils were randomly divided into three groups ( 8 gerbils in each group) for FSH, LH, and PRL assays, respectively. The virgin female gerbils were paired with experienced males in the afternoon and were examined by vaginal smear the next morning. The day on which sperm were found in the vaginal smear was designated as day 0 of gestation. The male was removed when the female was confirmed as pregnant. The parturition day was regarded as the last day of gestation and day 0 of lactation. The day when the pups were able to obtain food by themselves was regarded as the last day of lactation. The time from the end of lactation in primiparous gerbils to the estrous cycle in multiparous gerbils was about two weeks.

Blood sampling from female gerbils began in the virgin estrous cycle, and continued through gestation and lactation of primiparous gerbils, the post-weaning estrous cycle, and gestation and lactation as multiparous gerbils. Blood samples were taken every day during the estrous cycle and every 3 days during gestation and lactation. The sampling was conducted 42 times for each gerbil on the premise of its normal survival. Blood samples $(0.2-0.3 \mathrm{ml})$ were collected between 1400 and $1500 \mathrm{~h}$ via orbital venous puncture following light ether anaesthesia. Serum was separated by centrifugation at $1,000 \times g$ for $20 \mathrm{~min}$ at $4^{\circ} \mathrm{C}$ and stored at $-80^{\circ} \mathrm{C}$ until analysis. The study was conducted according to Guidelines for Animal Experiments and approved by the Animal Care and Use Committee of the China Agricultural University.

\section{Hormone assays}

Concentrations of FSH, LH, and PRL were measured in Mongolian gerbils using rat ELISA kits (EIAab Science Co., Ltd., Wuhan, China), as described and validated previously [27]. The limits of sensitivity were $0.078 \mathrm{mIU} / \mathrm{ml}$ for FSH, $0.195 \mathrm{mIU} / \mathrm{ml}$ for $\mathrm{LH}$, and 0.039 $\mathrm{ng} / \mathrm{ml}$ for PRL, respectively. The intra-assay variations for FSH, LH, and PRL were $4.8 \%$, while the inter-assay variations were $7.4 \%$.

\section{Statistical analysis}

Data distributions were analyzed for normality by the one-sample Kolmogorov-Smirnov test. The hormone data were analyzed by one-way ANOVA for repeated measures. Pearson correlation coefficients were calculated between hormone levels per reproductive state. Values were considered statistically significant at $P<0.05$ and highly significant at $P<0.01$. The analyses were performed using SPSS 16.0 for Windows. Data are presented as means $\pm \operatorname{SEM}(n=8)$. 

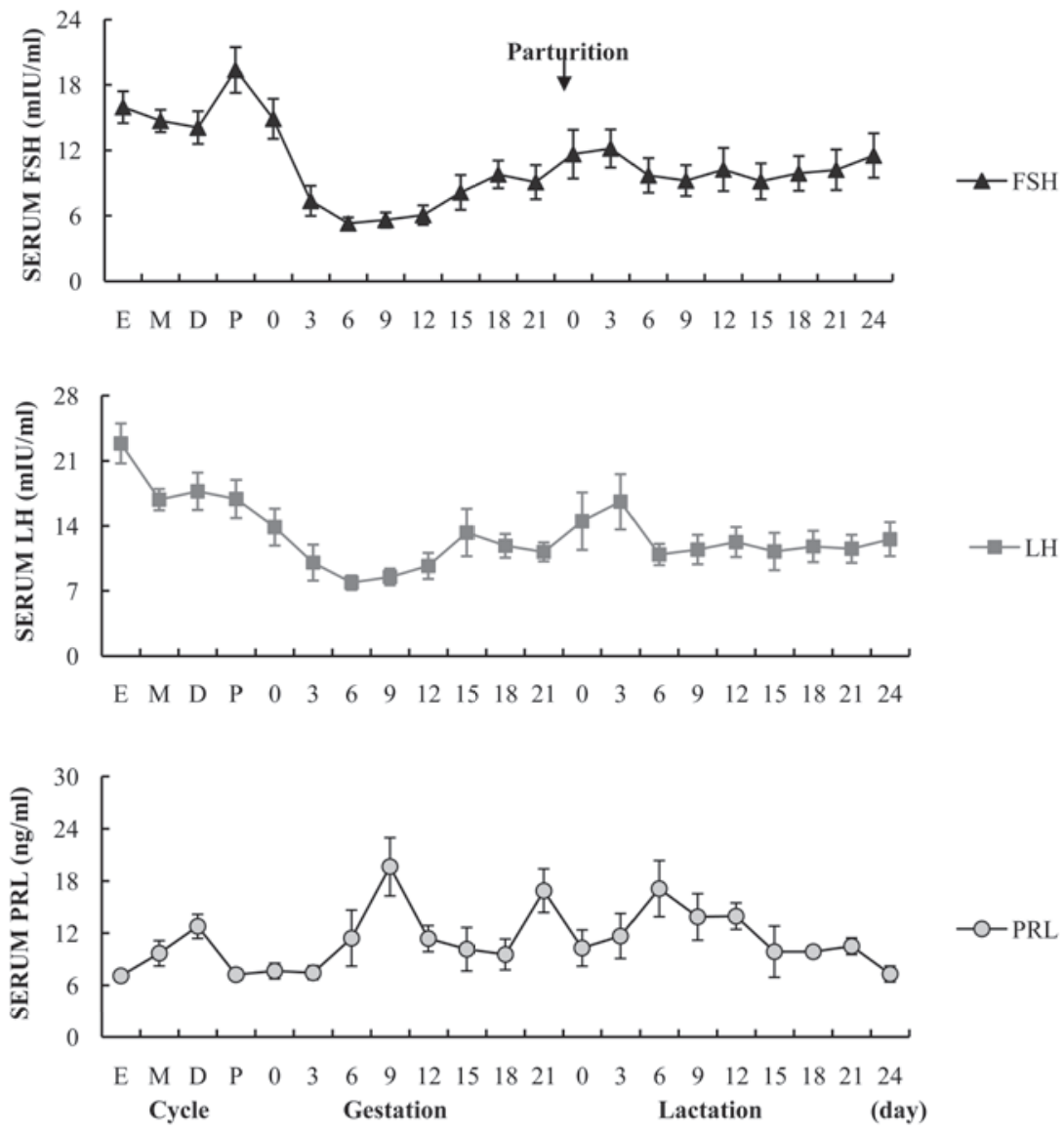

Fig. 1. Serum FSH, LH, and PRL levels during the virgin estrous cycle, gestation, and lactation in primiparous Mongolian gerbils. Each point represents the mean $\pm \mathrm{SEM}$ of 8 gerbils ( $\mathrm{E}, \mathrm{M}, \mathrm{D}, \mathrm{P}=$ estrus, metestrus, diestrus, proestrus, respectively. Gestation: 0-21 and lactation: 0-24).

\section{Results}

Hormonal variations during the estrous cycle of virgin Mongolian gerbils and gestation and lactation in primiparous gerbils (Fig. 1)

During the estrous cycle of virgin gerbils, serum FSH levels peaked at proestrus $(19.37 \pm 2.09 \mathrm{mIU} / \mathrm{ml})$, and were significantly higher than those at metestrus $(14.70$ $\pm 1.03 \mathrm{mIU} / \mathrm{ml})$ and diestrus $(14.09 \pm 1.50 \mathrm{mIU} / \mathrm{ml}$, $P<0.05)$, but not at estrus $(15.96 \pm 1.46 \mathrm{mIU} / \mathrm{ml}, P>0.05)$. Serum LH levels peaked at estrus $(22.87 \pm 2.15 \mathrm{mIU} /$ $\mathrm{ml})$, and were significantly higher than those at proestrus $(16.89 \pm 2.05 \mathrm{mIU} / \mathrm{ml})$ and metestrus $(16.82 \pm 1.15 \mathrm{mIU} /$ $\mathrm{ml}, P<0.05)$, but not diestrus $(17.72 \pm 2.01 \mathrm{mIU} / \mathrm{ml}$, $P>0.05)$. Serum PRL levels remained constant through proestrus $(7.72 \pm 0.35 \mathrm{ng} / \mathrm{ml})$, estrus $(7.10 \pm 0.25 \mathrm{ng} / \mathrm{ml})$, and metestrus $(9.68 \pm 1.46 \mathrm{ng} / \mathrm{ml})$, but peaked at diestrus $(12.78 \pm 1.39 \mathrm{ng} / \mathrm{ml}, P<0.05)$.

Primiparous gerbils had high serum FSH levels on day 0 of gestation $(14.89 \pm 1.83 \mathrm{mIU} / \mathrm{ml})$ when sperm were observed in the vaginal smear. The levels then rapidly decreased during early gestation, with the lowest levels recorded on day 6 of gestation $(5.31 \pm 0.55 \mathrm{mIU} / \mathrm{ml})$. Subsequently, serum FSH gradually increased and reached a minor peak on day $18(9.80 \pm 1.27 \mathrm{mIU} / \mathrm{ml})$, after which it remained relatively stable until the day of parturition $(11.65 \pm 2.23 \mathrm{mIU} / \mathrm{ml}, P>0.05)$. Serum $\mathrm{LH}$ was also high on day 0 of gestation $(13.86 \pm 1.98 \mathrm{mIU} /$ $\mathrm{ml}$ ), but rapidly decreased during early gestation, reaching its lowest point on day $6(7.89 \pm 0.77 \mathrm{mIU} / \mathrm{ml})$, after which it increased reaching a minor peak on day 15 of gestation $(13.28 \pm 2.54 \mathrm{mIU} / \mathrm{ml})$. LH levels then re- 
mained relatively stable until parturition day $(14.50 \pm$ $3.09 \mathrm{mIU} / \mathrm{ml}$ ). Serum PRL was low on day 0 of gestation $(7.65 \pm 0.89 \mathrm{ng} / \mathrm{ml})$, but rapidly increased and reached a maximum on day $9(19.63 \pm 3.34 \mathrm{ng} / \mathrm{ml})$. The levels then remained constant between days $12(11.37 \pm 1.50$ $\mathrm{ng} / \mathrm{ml})$ and $18(9.56 \pm 1.77 \mathrm{ng} / \mathrm{ml}, P>0.05)$, and peaked again on day $21(16.88 \pm 2.50 \mathrm{ng} / \mathrm{ml})$. Thereafter, the levels declined until parturition day $(10.29 \pm 2.08 \mathrm{ng} /$ $\mathrm{ml})$. Serum FSH levels were positively correlated with serum LH levels $(r=0.66, P<0.01)$ and negatively correlated with serum PRL levels $(r=-0.30, P<0.05)$, during gestation. However, there was no significant correlation between serum LH and PRL levels during gestation in primiparous gerbils $(P>0.05)$.

Serum FSH gradually increased from day 0 of lactation $(11.65 \pm 2.23 \mathrm{mIU} / \mathrm{ml})$ to day $3(12.17 \pm 1.75 \mathrm{mIU} /$ $\mathrm{ml}$ ) in primiparous gerbils. Subsequently, the levels decreased and did not significantly change between days $6(9.71 \pm 1.58 \mathrm{mIU} / \mathrm{ml})$ and $24(11.53 \pm 2.04 \mathrm{mIU} / \mathrm{ml}$, $P>0.05)$. Serum LH also gradually increased from day 0 of lactation $(14.50 \pm 3.09 \mathrm{mIU} / \mathrm{ml})$ to day $3(16.59 \pm$ $2.97 \mathrm{mIU} / \mathrm{ml})$, after which levels dropped until day 6 $(10.92 \pm 1.14 \mathrm{mIU} / \mathrm{ml})$ and remained stable until day 24 of lactation $(12.57 \pm 1.83 \mathrm{mIU} / \mathrm{ml}, P>0.05)$. Serum PRL rapidly increased from day $0(10.29 \pm 2.08 \mathrm{ng} / \mathrm{ml})$ of lactation to day $6(17.11 \pm 3.23 \mathrm{ng} / \mathrm{ml})$, followed by a decrease until day $24(7.31 \pm 0.91 \mathrm{ng} / \mathrm{ml})$. Serum LH levels were positively correlated with serum FSH levels $(r=0.71, P<0.01)$ as well as with serum PRL levels $(r=0.44, P<0.01)$ during lactation. There was no significant correlation between serum PRL and FSH levels during lactation in primiparous gerbils $(P>0.05)$.

Hormonal variations during the post-weaning estrous cycle, gestation, and lactation in multiparous Mongolian gerbils (Fig. 2)

During the post-weaning estrous cycle, serum FSH peaked at proestrus $(25.06 \pm 2.46 \mathrm{mIU} / \mathrm{ml})$, with levels significantly higher than those at estrus $(17.78 \pm 0.44$ $\mathrm{mIU} / \mathrm{ml})$ and metestrus $(19.69 \pm 1.60 \mathrm{mIU} / \mathrm{ml}, P<0.05)$, but not diestrus $(21.04 \pm 1.62 \mathrm{mIU} / \mathrm{ml}, P>0.05)$. Serum LH peaked at estrus $(29.55 \pm 3.00 \mathrm{mIU} / \mathrm{ml})$, with levels significantly higher than those at proestrus $(19.47 \pm 2.02$ $\mathrm{mIU} / \mathrm{ml})$ and diestrus $(19.59 \pm 2.51 \mathrm{mIU} / \mathrm{ml}, P<0.05)$, but not metestrus $(22.89 \pm 1.49 \mathrm{mIU} / \mathrm{ml}, P>0.05)$. Serum
PRL peaked at diestrus $(8.37 \pm 0.28 \mathrm{ng} / \mathrm{ml})$, with levels significantly higher than those at estrus $(4.85 \pm 0.71 \mathrm{ng} /$ $\mathrm{ml})$ and metestrus $(4.87 \pm 0.94, P<0.05)$, but not proestrus $(6.12 \pm 0.80 \mathrm{ng} / \mathrm{ml}, P>0.05)$.

In multiparous gerbils, serum FSH levels declined from day $0(18.13 \pm 1.73 \mathrm{mIU} / \mathrm{ml})$ to day $12(6.92 \pm 1.13$ $\mathrm{mIU} / \mathrm{ml}$ ) of gestation, after which they remained relatively stable from day $15(11.52 \pm 1.65 \mathrm{mIU} / \mathrm{ml})$ to parturition day $(9.66 \pm 3.16 \mathrm{mIU} / \mathrm{ml}, P>0.05)$. Serum $\mathrm{LH}$ also gradually decreased from day 0 of gestation (24.19 $\pm 1.95 \mathrm{mIU} / \mathrm{ml})$ to day $12(10.60 \pm 0.97 \mathrm{mIU} / \mathrm{ml})$, and remained relatively constant between days 15 (16.16 \pm $1.71 \mathrm{mIU} / \mathrm{ml})$ and $24(11.68 \pm 1.12 \mathrm{mIU} / \mathrm{ml}, P>0.05)$. Serum PRL rapidly increased from day 0 of gestation $(6.40 \pm 1.50 \mathrm{ng} / \mathrm{ml})$, reaching a peak on day $6(12.10 \pm$ $2.24 \mathrm{ng} / \mathrm{ml})$. The levels then declined and remained stable between days $12(5.56 \pm 0.86 \mathrm{ng} / \mathrm{ml})$ and 18 of gestation $(6.29 \pm 0.63 \mathrm{ng} / \mathrm{ml}, P>0.05)$, after which they peaked on day $21(10.17 \pm 1.92 \mathrm{ng} / \mathrm{ml})$. Thereafter, the levels rapidly decreased until parturition day $(4.50 \pm$ $0.60 \mathrm{ng} / \mathrm{ml})$. Serum LH levels were positively correlated with FSH levels during gestation $(r=0.36, P<0.05)$, and negatively correlated with PRL levels during the first half of gestation $(r=-0.55, P<0.05)$. There was no significant correlation between serum FSH and PRL levels during gestation in multiparous gerbils $(P>0.05)$.

During lactation, serum FSH showed a rapid rise from day $0(9.66 \pm 3.16 \mathrm{mIU} / \mathrm{ml})$ to day $3(14.76 \pm 2.35 \mathrm{mIU} /$ $\mathrm{ml})$. The levels then declined from day 3 to day $6(10.70$ $\pm 2.32 \mathrm{mIU} / \mathrm{ml}$ ), and remained constant between days 6 to $24(13.23 \pm 2.77 \mathrm{mIU} / \mathrm{ml}, P>0.05)$. Serum LH rapidly increased from day $0(11.68 \pm 1.12 \mathrm{mIU} / \mathrm{ml})$ to day $3(19.11 \pm 1.17 \mathrm{mIU} / \mathrm{ml})$, and gradually declined from day 3 to day $9(13.82 \pm 2.08 \mathrm{mIU} / \mathrm{ml})$. The levels remained relatively stable from day 9 to day 24 (17.75 \pm $2.69 \mathrm{mIU} / \mathrm{ml}, P>0.05)$. Serum PRL rapidly increased from day $0(4.50 \pm 0.60 \mathrm{ng} / \mathrm{ml})$, reaching a peak on day $9(9.47 \pm 1.32 \mathrm{ng} / \mathrm{ml})$, followed by a gradual decline till day $24(5.64 \pm 0.79 \mathrm{ng} / \mathrm{ml})$. There was no significant correlation between serum FSH, LH, and PRL levels during lactation in multiparous gerbils $(P>0.05)$. 

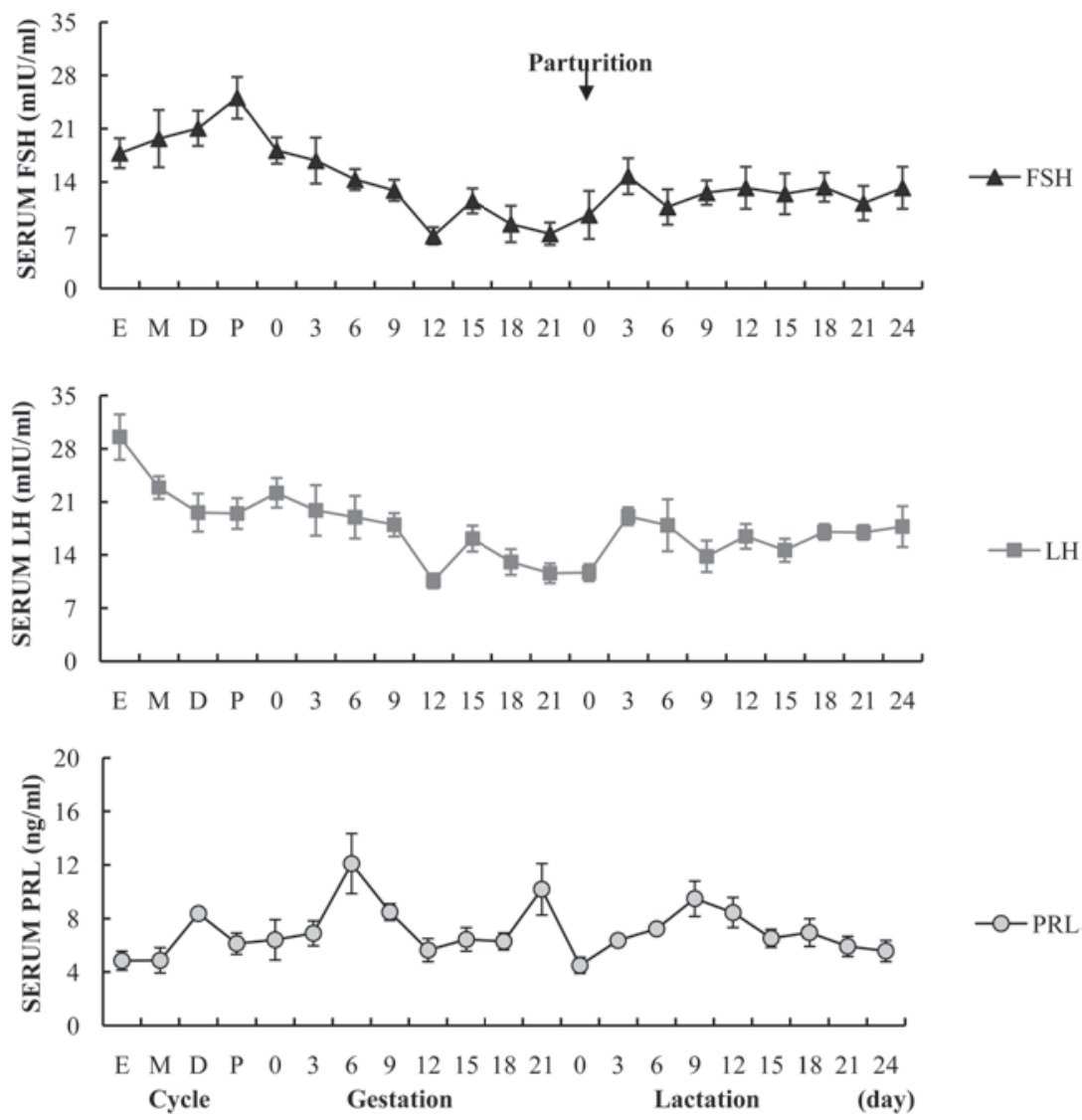

Fig. 2. Serum FSH, LH, and PRL levels during the post-weaning estrous cycle, gestation, and lactation in multiparous Mongolian gerbils. Each point represents the mean \pm SEM of 8 gerbils (E, M, D, P=estrus, metestrus, diestrus, proestrus, respectively. Gestation: 0-21 and lactation: 0-24).

\section{Discussion}

Hormonal variations during the estrous cycle in virgin Mongolian gerbils

Changing patterns of gonadotropin and prolactin levels during the estrous cycle correlated with ovulation and the maintenance of the estrous cycle in Mongolian gerbils. Gonadotropin and prolactin play an important role in regulating the estrous cycle of Mongolian gerbils. It is widely accepted that preovulatory surges of gonadotropins play a crucial role in ovulation and in the formation of the corpus luteum (CL). Ovulation in Mongolian gerbils usually occurs between 6 and $10 \mathrm{~h}$ after the onset of estrus, which is most frequently observed between 1700 to $2000 \mathrm{~h}[18,25]$. A peak in estradiol at proestrus [15] leads to the release of gonadotropin-re- leasing hormone causing a primary surge in FSH with a concomitant surge in LH in Mongolian gerbils. The surges of gonadotropins initiate ovulation in Mongolian gerbils. Functional demise and structural luteolysis are necessary to maintain cyclicity and to avoid accumulation of non-functional luteal tissue within the ovary [29]. The surge in PRL levels at diestrus is presumed to initiate the regression of the $\mathrm{CL}$ of the preceding cycle. The primary action of prolactin during the estrous cycle in Mongolian gerbils may be luteolytic ensuring the normal cyclicity of the estrous cycle.

The phases during which surges of FSH, LH, and PRL occur in Mongolian gerbils are different from those of rats [30] and mice [20,23]. Contrary to the results of this study, FSH, LH, and PRL levels during the estrous cycle in Mongolian gerbils have been reported to peak 
at metestrus, estrus, and diestrus, respectively [27].

\section{Hormonal variations during gestation in primiparous Mongolian gerbils}

Serum gonadotropin and prolactin levels vary in order to favor implantation, decidualization, luteal function maintenance, placental development, and parturition initiation during gestation. Prolactin plays an important role in the progression of gestation in Mongolian gerbils. Normally, in Mongolian gerbils, gestation lasts for 24-26 days, and implantation occurs on day 7 of gestation [3, 18]. Decidualization is required for the implantation and maintenance of gestation [19]. The decidual reaction at maximum development occurs during the 2 days following implantation in Mongolian gerbils [3]. Prolactin is a specific decidual marker $[14,28]$. The peak of PRL levels on day 6 or 9 during gestation is related to the decidual reaction of Mongolian gerbils. During early gestation in Mongolian gerbils, high prolactin levels maintain the integrity of CL progesterone ( $\mathrm{P} 4)$ production, which is necessary for successful implantation. This phenomenon has also been observed in rats [6]. The rapid increase in progesterone levels during the first half of gestation in Mongolian gerbils [15] may be attributable to the PRL stimulus. PRL may play a critical role in CL maintenance and progesterone production in Mongolian gerbils. Serum gonadotropin levels were lower during the first half than in the second half of gestation. These changes may possibly be due to the effects of progesterone. Serum P4 levels during gestation were higher in the first half than in the second half of gestation in Mongolian gerbils $[9,15]$. The suppressive effects of progesterone on gonadotropin levels during early gestation have been observed in rats $[1,11]$.

Prolactin is sufficient for maintaining luteal function in the first half of gestation in Mongolian gerbils, but the responsiveness of luteal cells to PRL decreases from early pregnancy to mid- and late gestation $[6,26]$. Placental development in Mongolian gerbils occurs from day 13 till term [3]. The luteotropic hormones produced by the placenta maintain the functional integrity of the CL after pituitary PRL surges end during mid-gestation in Mongolian gerbils, as well as in rats and mice [31]. A PRL peak prior to parturition in Mongolian gerbils is required for parturition initiation. This has also been observed in rats and mice [7, 17]. The rise of serum FSH and LH from days 21 to 24 of gestation occurs possibly in preparation for the onset of postpartum estrus and ovulation in Mongolian gerbils.

The changes in gonadotropin levels during gestation observed in this study were similar to those reported in rats [21, 34] but different from those seen in mice [22], whereas the changing pattern of PRL levels was different from that of rats [34] and similar to that observed in mice [22].

Hormonal variations during lactation in primiparous Mongolian gerbils

Variations in gonadotropin and prolactin are necessary for initiating lactation and are associated with postpartum estrus and the suckling stimulus in Mongolian gerbils. Postpartum estrus commonly occurs 1 or 2 days after parturition in Mongolian gerbils [18]. The process of parturition actively contributes to the stimulation of the postpartum gonadotropin surges [5]. From day 1 to day 3 of lactation, high levels of gonadotropin correlated with post-partum ovulation in Mongolian gerbils, which is a result similar to that reported for rats $[2,8$, 21]. In contrast to rats [8], the prolactin surge during post-partum estrus in Mongolian gerbils is not obvious. Following parturition, the suppression of ovarian activity by the onset of a rapid rise in PRL levels, was associated with a profound decline in serum FSH and LH levels in Mongolian gerbils. This finding is similar to that reported in rats $[32,34]$.

Gonadotropin levels from day 6 to day 24 of lactation were found to be relatively stable in Mongolian gerbils. This may be explained by the fact that the suckling stimulus suppresses gonadotropin secretion during the first half of lactation $[12,33]$ and inhibin may play a primary role in the suppression of FSH secretion, whereas ovarian steroids have been shown to play a primary role in the suppression of LH secretion during the second half of lactation [33]. Similar to the levels reported in rats [8], PRL levels in Mongolian gerbils during early lactation were high and subsequently decreased. This may be caused by the strong suckling stimulus during the first half of lactation, and a waning in the suckling stimulus during the second half.

During lactation, the changing patterns of serum FSH, 
LH, and PRL were similar to those reported for rats. [34].

Hormonal variations during different reproductive states in multiparous Mongolian gerbils

Changes in gonadotropin and prolactin levels during different reproductive states were similar in primiparous and multiparous gerbils. During the post-weaning estrous cycle, the phases during which gonadotropin and prolactin peaked were the same as those observed during the estrous cycle in virgin Mongolian gerbils. During gestation, changing patterns of gonadotropin and prolactin in multiparous and primiparous gerbils were similar, although the days on which the lowest gonadotropin levels were observed and the peak in prolactin occurred were different. Serum LH is higher in the first half than in the second half of gestation, in rats [21]. However, this was not observed in Mongolian gerbils. During lactation, changes in gonadotropin levels were similar in primiparous and multiparous gerbils. Similar to rats, multiparous gerbils have attenuated sucklinginduced PRL secretion as compared to primiparous gerbils [16].

In summary, changing patterns of gonadotropin and prolactin levels correlated with the reproductive stages of Mongolian gerbils. Gonadotropin and prolactin play important roles in regulating the estrous cycle, gestation, and lactation in Mongolian gerbils. Variations in gonadotropin during the estrous cycle, gestation, and lactation in Mongolian gerbils and other rodents such as rats are similar. However, this was not true for the variation in PRL levels, except during lactation. Changes in gonadotropin and prolactin levels during different reproductive states were found to be similar in primiparous and multiparous gerbils. Although the more precise variations of reproductive hormones remain to be investigated, this study provides additional information regarding their secretion patterns in Mongolian gerbils.

\section{Acknowledgments}

We thank Dr. Yong-Song CAO and Dr. Yan-Ling WANG for reviewing this manuscript and their critical comments. The work was supported by the National Key Basic Research and Development Program of Chi- na (No. 2007CB 109105), and the National Key Technology Research and Development Program of China (No. 2006BAD16B04-1).

\section{References}

1. Brown-Grant, K., Corker, C.S., and Naftolin, F. 1972. Plasma and pituitary luteinizing hormone concentrations and peripheral plasma oestradiol concentration during early pregnancy and after the administration of progestational steroids in the rat. J. Endocrinol. 53: 31-35.

2. Diebel, N.D. and Bogdanove, E.M. 1978. Analysis of luteinizing hormone and follicle-stimulating hormone release kinetics during a dynamic secretory event, the postpartum preovulatory surge in the rat, based on quantitative changes in stored and circulating luteinizing hormone and follicle-stimulating hormone and metabolic clearance data for these hormones. Endocrinology 103: 665-673.

3. Fischer, T.V. and Floyd, A.D. 1972. Placental development in the Mongolian gerbil (Meriones unguiculatus). I. Early development to the time of chorio-allantoic contact. Am.J. Anat. 134: 309-320.

4. Fochi, R.A., Perez, A.P.S., Bianchi, C.V., Rochel, S.S., Góes, R.M., Vilamaior, P.S.L., Taboga, S.R., and Santos, F.C.A. 2008. Hormonal oscillations during the estrous cycle influence the morphophysiology of the gerbil (Meriones unguiculatus) female prostate (skene paraurethral glands). Biol. Reprod. 79: 1084-1091.

5. Fox, S.R. and Smith, M.S. 1984. Postpartum preovulatory surge of gonadotropin secretion in the rat may be initiatied by the labor process. Biol. Reprod. 31: 619-626.

6. Gafvels, M., Bjurulf, E., and Selstam, G. 1992. Prolactin stimulates the expression of luteinizing hormone/chorionic gonadotropin receptor messenger ribonucleic acid in the rat corpus luteum and rescues early pregnancy from Bromocriptin-induced abortion. Biol. Reprod. 47: 534540 .

7. Grattan, D. and Averill, R.L.W. 1990. Effect of ovarian steroids on a nocturnal surge of prolactin secretion that precedes parturition in the rat. Endocrinology 126: 11991205 .

8. Honda, K., Sugawara, S., and Masaki, J. 1977. Serum levels of progesterone, prolactin, $\mathrm{LH}$ and FSH during lactation in the rat. Tohoku J. Agric. Res. 28: 135-144.

9. Kai, O., Hiramatsu, Y., Sonoda, Y., Sensui, N., and Imai, K. 1997. Plasma progesterone concentrations during pregnancy and lactation in Mongolian gerbils (Meriones unguiculatus). Exp. Anim. 46: 283-288.

10. Kai, O., Sonoda, Y., Sensui, N., and Imai, K. 1999. Effect of litter size on gestation length and plasma progesterone concentration in Mongolian gerbils (Meriones unguiculatus). Anim. Sci. J. 70: 18-23.

11. Labhsetwar, A.P. 1973. Pituitary gonadotrophic function (FSH and LH) in various reproductive states. Adv. Reprod. Physiol. 6: 97-183. 
12. Lu, K.H., Chen, H.T., Huang, H.H., Grandison, L., Marshall, S., and Meites, J. 1976. Relation between prolactin and gonadotrophin secretion in post-partum lactating rats. $J$. Endocrinol. 68: 241-250.

13. Luo, Z.X., Chen, W., Gao, W., Wang, Y.X., Li, C.Y., Li, H., Huang, W.J., Lu, M.F., Wen, Y.X., Zhou, M.Z., Shou, Z.C., Zhang, W.S., and Hou, L.X. 2000. Rodentia Part III: Cricetidae. pp. 121-128. In: Fauna Sinica Mammalia, Vol. 6, Science Press, Beijing (in Chinese).

14. Lynch, V.J., Tanzer, A., Wang, Y., Leung, F.C., Gellersen, B., Emera, D., and Wagner, G.P. 2008. Adaptive changes in the transcription factor HoxA-11 are essential for the evolution of pregnancy in mammals. Proc. Natl. Acad. Sci. U.S.A. 105: 14928-14933.

15. Lv, X.H. and Shi, D.Z. 2010. Variations of serum estradiol and progesterone levels during consecutive reproductive states in Mongolian gerbils (Meriones unguiculatus). Exp. Anim. 59: 231-237.

16. Mann, P.E. and Bridges, R.S. 1992. Neural and endocrine sensitivities to opioids decline as a function of multiparity in the rat. Brain Res. 580: 241-248.

17. Markoff, E. and Talamantes, F. 1981. Serum placental lactogen in mice in relation to day of gestation and number of conceptuses. Biol. Reprod. 24: 846-851.

18. Marston, J.H. and Chang, C. 1965. The breeding, management, and reproductive physiology of the Mongolian gerbil (Meriones unguiculatus). Lab. Anim. Care 15: 3448.

19. Matsumoto, H., Sakai, K., and Iwashita, M. 2008. Insulinlike growth factor binding protein-1 induces decidualization of human endometrial stromal cells via $\alpha 5 \beta 1$ integrin. Mol. Hum. Reprod. 14: 485-489.

20. Michael, S.D. 1976. Plasma prolactin and progesterone during the estrous cycle in the mouse. Proc.Soc. Exp. Biol. Med. 153: 254-257.

21. Morishige, W.K., Pepe, G.J., and Rothchild, I. 1973. Serum luteinizing hormone, prolactin and progesterone levels during pregnancy in the rat. Endocrinology 92: 15271530 .

22. Murr, S.M., Bradford, G.E., and Geschwind, I.I. 1974. Plasma luteinizing hormone, follicle-stimulating hormone and prolactin during pregnancy in the mouse. Endocrinology
94: 112-116.

23. Murr, S.M., Geschwind, I.I., and Bradford, G.E. 1973. Plasma LH and FSH during different oestrous cycle conditions in mice. J. Reprod. Fert. 32: 221-230.

24. Neumann, K., Maak, S., Stuermer, I.W., von Lengerken, G., and Gattermann, R. 2001. Low microsatellite variation in laboratory gerbils. J. Hered. 92: 71-74.

25. Nishino, N. and Totsukawa, K. 1996. Study on the estrous cycle in the Mongolian gerbil (Meriones unguiculatus). Exp. Anim. 45: 283-288.

26. Niswender, G.D., Juengel, J.L., McGuire, W.J., Belfiore, C.J., and Wiltbank, M.C. 1994. Luteal function: the estrous cycle and early pregnancy. Biol. Reprod. 50: 239-247.

27. Parkening, T.A., Collins, T.J., and Smith, E.R. 1984. Plasma and pituitary concentrations of LH, FSH and prolactin in aging Mongolian gerbils. Exp. Gerontol. 19: 359-365.

28. Prigent-Tessier, A., Tessier, C., Hirosawa-Takamori, M., Boyer, C., Ferguson-Gottschall, S., and Gibori, G. 1999. Rat decidual prolactin. Identification, molecular cloning, and characterization. J. Biol. Chem. 274: 37982-37989.

29. Rothchild, I. 1981. The regulation of the mammalian corpus luteum. Recent Prog. Horm. Res. 37: 183-295.

30. Smith, M.S., Freeman, M.E., and Neill, J.D. 1975. The control of progesterone secretion during the estrous cycle and early pseudopregnancy in the rat: prolactin, gonadotropin and steroid levels associated with rescue of the corpus luteum of pseudopregnancy. Endocrinology 96: 219-226.

31. Soares, M.J., Faria, T.N., Roby, K.F., and Deb, S. 1991. Pregnancy and the prolactin family of hormones: coordination of anterior pituitary, uterine, and placental expression. Endocr. Rev. 12: 402-423.

32. Taya, K. and Sasamoto, S. 1981. Changes in FSH, LH and prolactin secretion and ovarian follicular development during lactation in the rat. Endocrinol. Jpn. 28: 187-196.

33. Taya, K. and Sasamoto, S. 1991. Mechanisms responsible for suppression of FSH and LH during lactation in the rat. J. Endocr. 129: 119-130.

34. Yohkaichiya, T., O'Connor, A., and de Kretser, D.M. 1991. Circulating immunoreactive inhibin, gonadotropin, and prolactin levels during pregnancy, lactation, and postweaning estrous cycle in the rat. Biol. Reprod. 44: 6-12. 